\title{
Does January Effect Exist in Bangladesh?
}

\author{
A. F. M. Mainul Ahsan ${ }^{1} \&$ Ahasan H Sarkar ${ }^{2}$ \\ ${ }^{1}$ School of Business, Independent University, Bangladesh (IUB) \\ 2 The University of Sydney, Australia \\ Correspondence: A. F. M. Mainul Ahsan, School of Business, Independent University, Bangladesh (IUB). Tel: \\ 880-171-7012-818. E-mail: mainul188@gmail.com \\ Received: Jaunary 25, 2013 \\ Accepted: February 21, 2013 \\ Online Published: March 14, 2013 \\ doi:10.5539/ijbm.v8n7p82 \\ URL: http://dx.doi.org/10.5539/ijbm.v8n7p82
}

\begin{abstract}
This paper examines existence of January effect in Dhaka Stock Exchange (DSE) in Bangladesh. Regression model combined with dummy variables and monthly DSE All Share Price Index (DSI) from January 1987 to November 2012 has been used to test January effect in the stock return in DSE. It was empirically found that, although January anomaly doesn't exist in DSE, there is significant positive return in June which raises question against efficient market hypothesis (EMH). Thus, there is an opportunity for investors to take advantage of this June anomaly.
\end{abstract}

Keywords: January effect, turn-of-the-year effect, window-dressing, tax-loss selling, efficient market hypothesis

\section{Introduction}

The introduction of the Efficient Market Hypothesis (EMH) by Fama (1970) led to numerous empirical studies to examine the randomness of stock price movements. EMH basically posits that past stock prices should have no predictive power of future prices, i.e., stock prices should be random. However, plethora of researches has been conducted to show that market inefficiencies do exist. For example, EMH has been tested worldwide by a number of calendar anomalies, e.g., days of the weak effect, month of the year effect, January effect, holiday effect, etc. Anomalies allow investors to foretell stock price movements, and thus help to generate abnormal return by taking advantage of those stock market inefficiencies.

The objective of this paper is to study the existence of "turn-of-the-year" or "January effect" in stock returns in Dhaka Stock Exchange (DSE) in Bangladesh. The January effects a seasonal irregularity of the financial market where stock prices tend to fall towards the end of December and then recuperate quickly in the first month of the New Year, i.e., January.

Monthly value of DSE All Share Price Index (DSI) for 26 years, i.e., 1987 to 2012, has been employed for detecting January effect in DSE. Regression models coupled with dummy variables is used to test the existence of January effect. Even though results of this study confirmed "June effect" in the stock return in DSE, January effect was not detected.

Section 2 of this study lists previous studies related to January anomaly in the U. S. and around the globe. Section 3 describes data collection and explains methodology. Section 4 discusses results of the research. Lastly, section 5 provides concluding remarks on the study with a note on media accountability.

\section{Literature Review}

Although the January effect was brought to the attention of modern finance by Rozeff and Kinney (1976), Wachtel (1942) was the first to examine seasonality in the Dow Jones Industrial Average (DJIA) Index from 1927 to 1942 . He documented frequent bullish tendencies from December to January in eleven of the fifteen years he studied. His study is based on the following three assumptions (Shin, 2003): (1) The high-yielding stocks are usually the stocks whose prices have decreased, and they are the best stocks to sell in December to get tax benefit, (2) individuals and corporations sell stocks for tax-saving at the middle of December to establish tax losses, and such pressures drives security prices below what they should be according to potential earnings, (3) the rise at the year's end is nothing more than a normal reaction from depressed levels.

Rozeff and Kinney (1976) calculated that the average return on an equal-weighted NYSE index from 1904 
through 1974 was 3.48 percent during January and only about 0.42 percent during the remaining 11 months of the year. Hence, January returns appeared to be more than eight times higher than returns during a typical month. Branch (1977), Dyl (1977), Keim (1983), Reinganum (1983), Haugen and Jorion (1996), Mehdian and Perry (2002) also confirmed existence of the January effect in the U. S. stock markets. Gultekin and Gultekin (1983) reported international evidence of "January effect" and therefore makes this a global issue.

Schwert (2003) concluded that the January effect weakened in the period from 1980-2001, but that it still existed. Moosa (2007), using monthly average returns of the U.S. stocks for period of 1970 to 2005, showed that a significant January effect existed except for the period 1990-2005 where negative July effect dominated. Mehdian and Perry (2002) reported that while January mean returns are positive in U.S. stock markets, they are not statistically significant after the 1987 U.S. stock market crash. Lindley, Liano and Slater (2004) demonstrated that many years during the period 1962-2000 did not have a significant January effect and that some years had a negative January effect.

Since an equally-weighted NYSE index represents a simple average of the stock prices for all listed firms, the Rozeff and Kinney (1976) methodology gives smaller companies greater relative influence than would be true for a value weighted index where large firms dominate. Keim (1983) found that January effect is more significant for small firms and, half of the January returns came during the first five days of the month, particularly on the first trading day. Subsequent research by Reinganum (1983) and Roll (1983), among others, confirms the fact that this January effect is a small cap phenomenon. Using Markov-switching model, Rathinasamy (2004) analyzed the monthly stock returns for the period 1926-1992 but did not found any significant January effect. However, for small firms in terms of capitalization, very strong January effect existed.

January effect has also been detected in Canada (Berges, McConnell, \& Schlarbaum, 1984), Japan (Kato \& Schallheim, 1985), Malaysian (Nassir \& Mohammad, 1987), U.K. (Mills \& Coutts, 1995), Greece (Mills, Siriopoulos, Markellos \& Harizanis, 2000), Chile, Greece, Korea, Taiwan and Turkey (Fountas \& Segredakis, 2002), India (Pandey, 2002), Sweden (Hellstrom, 2002), Nepal (Bahadur \& Joshi, 2005), Poland, Romania, Hungary and Slovakia (Asteriou \& Kovetsos, 2006), Argentina (Rossi, 2007). However, conflicting results are also available. For instance, January effect in Jordon (Maghayereh, 2003), Greece (Flores, 2008), Brazil, Chile and Mexico (Rossi, 2007) wasn't detected.

Using daily DSE composite index data from December 1988 to November 2001, Chowdhury (2005) found turn of the year effects for both traditional (English) and the financial year in Bangladesh. He found that the first day of January produces on average $0.45491 \%$ return per day(or, $125 \%$ annual return) and the last day of the financial year, i.e., June, generates significantly positive return, which is as high as staggering $1.20135 \%$ daily (or $330 \%$ annually).

Suggested explanations of the January effect comprise tax-loss selling, window dressing, increased liquidity in December, and new information effect. Tax-loss selling hypothesis (Branch, 1977) asserts that in December, i.e., end of tax year, investors tend to sell out the stocks held to realize capital losses. This helps them in reducing tax paid by them on their gains. As a result of this downward trend in market, stock prices go down. As the new tax year starts in January, investors again start to buy stocks and this upward drift pushes the stock prices up. Window dressing hypothesis (Haugen \& Lakonishok, 1988) posits that, to manipulate their performance, fund managers, avoid showing losers at their credit at year end, and thus start selling loser stocks from their fund and let only the winners stay in their portfolio. However, on January, fund managers reverse their action and start selling winners and put small stocks back in the portfolio. These window dressing actions by the fund managers create artificial downward pressure (and low returns) in December and upward pressure in the market (and high returns) in January.

Liquidity hypothesis (Ogden, 1990) states that January anomaly takes place as increased cash-flows, because of extra holiday payments, holiday gifts, and annual bonuses, poured in the stock market directly by individual investors or through mutual funds and pension funds. Investment decisions also likely to be made in January so there is a buying pressure during this month. New information hypothesis is based on the idea that stock prices tend to change as new information land in the marketplace. Positive new information pushes the stock price upward, and vice versa. Plethora of information lands in the market in first few days of January results in January effect (Rozeff \& Kinney, 1976). 


\section{Data and Research Methodology}

\subsection{Data}

This Section offers a brief description of the empirical setting and the data set. Monthly observations, for the period January, 1987 through November, 2012, of DSE All Share Price Index (DSI) are used to investigate the turn of the year effect in Dhaka Stock Exchange (DSE) in Bangladesh. DSI is a value-weighted index which includes all the stocks listed on the DSE. All the index data has been collected from the Dhaka Stock Exchange library.

\subsection{Methodology}

Monthly return of DSI Index is calculated as the natural log of [today's Index Value / previous day's Index Value]:

$$
R_{t}=\operatorname{In}\left(\frac{P_{t}}{P_{t-1}}\right)
$$

Where:

$R_{t}=$ Monthly return of DSI Index.

$P_{t}=$ Closing value of DSI Index at time t.

$P_{t-1}=$ Closing value of DSI Index at time $\mathrm{t}-1$.

The reasons to choose logarithm returns over general return are justified by both theoretically and empirically. Theoretically, logarithmic returns are analytically more tractable when linking together sub-period returns to form returns over longer intervals. Empirically, logarithmic returns are more likely to be normally distributed which is prior condition of standard statistical techniques (Strong, 1992).

To test the existence of monthly seasonality, the following basic regression model is used:

$$
\begin{aligned}
& R_{t}=C+\beta_{2} D_{\text {Feb }}+\beta_{3} D_{\text {Mar }}+\beta_{4} D_{\text {Apr }}+\beta_{5} D_{\text {May }}+\beta_{6} D_{\text {Jun }}+\beta_{7} D_{\text {Jul }}+\beta_{8} D_{\text {Aug }}+\beta_{9} D_{\text {Sep }}+\beta_{10} D_{\text {Oct }} \\
& +\beta_{11} D_{\text {Nov }}+\beta_{12} D_{\text {Dec }}+\mu_{t}
\end{aligned}
$$

Where, $R_{t}$ is the monthly return and the intercept term, $C$, indicates the average return for January. $D_{i}$ is a dummy variable that takes the value of 1 in month and $i$ zero otherwise. For instance, $D_{F e b}=1$ if the return is on February and 0 otherwise; $D_{\text {Mar }}=1$ if the return is on March and 0 otherwise; $D_{D e c}=1$ if the return is on December and 0 otherwise and so on. The OLS coefficients $\beta_{2}$ to $\beta_{12}$ indicate the difference in return between January and the $i$ th month of the year. The stochastic disturbance term is denoted by $\mu_{t}$.

\section{Analysis of Data and Results}

Movement of the DSE All Share Price Index (DSI) for the whole sample period, i.e., from February, 1987 to November, 2012 is shown in figure 1.

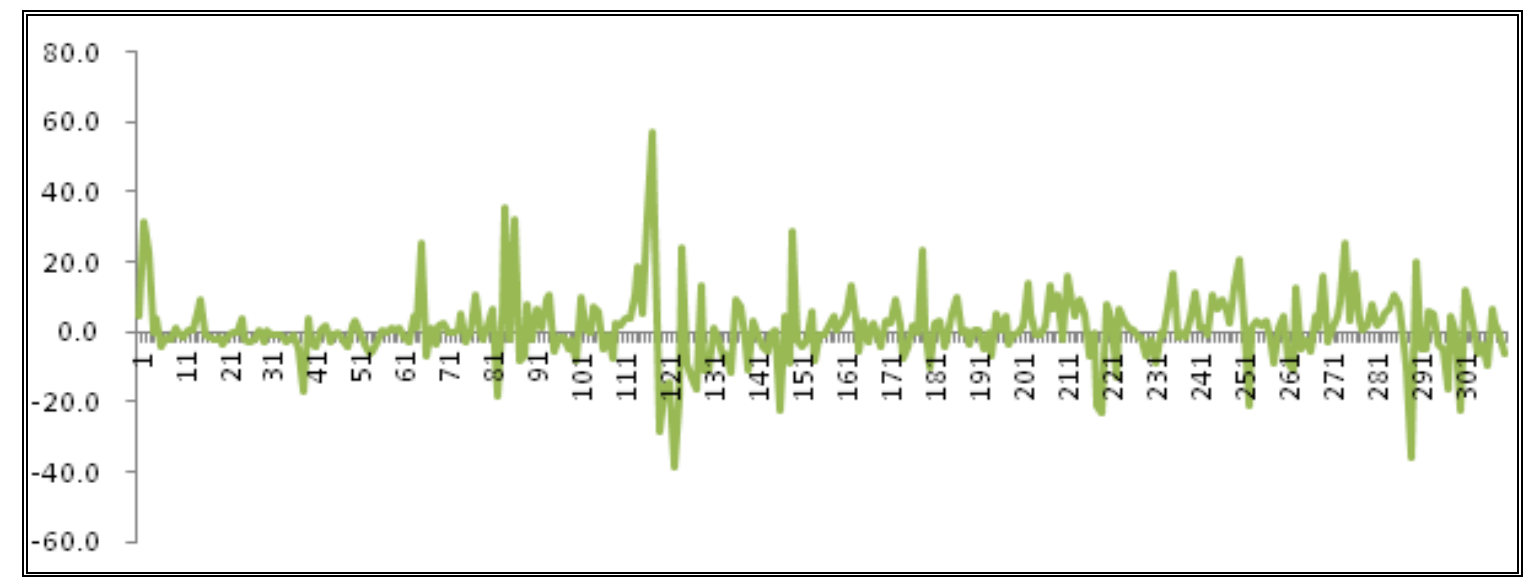

Figure 1. DSI monthly return during 1987-2012(\%)

Return data has been tested for unit roots employing the augmented Dickey-Fuller (ADF) test. The results of the 
ADF test, presented in table 1 , leads to rejection of the hypothesis of a unit root, so that the monthly DSE returns series can be taken to be stationary.

Table 1. Test for unit roots

\begin{tabular}{|c|c|c|}
\hline & ADF with constant & ADF without constant \\
\hline \multirow[t]{2}{*}{1 lag } & -11.6882 & -11.7343 \\
\hline & $(5.229 \mathrm{e}-024)^{* * *}$ & $(7.683 \mathrm{e}-025)^{* * *}$ \\
\hline \multirow[t]{2}{*}{5 lag } & -7.38915 & -7.46633 \\
\hline & $(1.826 \mathrm{e}-012)^{* * *}$ & $(1.71 \mathrm{e}-011)^{* * *}$ \\
\hline \multirow[t]{2}{*}{10 lag } & -4.93985 & -5.02877 \\
\hline & $(9.961 \mathrm{e}-007)^{* * *}$ & $(1.782 \mathrm{e}-005)^{* * *}$ \\
\hline
\end{tabular}

Note: figures in the parentheses show p-values. ${ }^{* * *}$ indicates significant at $1 \%$ level.

Table 2 presents summary statistics for the whole sample period. The maximum return during in the whole sample period is $\approx 56.93$ percent which took place in October 1996, right before the epic market crash on the same year. Even though there were two massive market crashes in Bangladesh in 1996 and 2010, the average monthly return for the entire period from 1987 to 2012 is 0.7996 percent market, on average, experiences negative return from December to April. While February suffers lowest return, June observes the highest return in stock market in Bangladesh. Returns exhibit negative skewness (i.e., data are skewed to the left) for four months and positive skewness (i.e., data are skewed to the right) for eight months. Five months have kurtosis greater than three which represents leptokurtic distribution, i.e., flatter tails than the normal distribution.

Table 2. Summary statistics for 1987-2012

\begin{tabular}{lccccccc}
\hline & Mean & Minimum & Maximum & Kurtosis & Skewness & p-value & N \\
\hline January & -0.0196 & -0.2283 & 0.3576 & 4.2594 & 1.2512 & 00 & 25 \\
February & -0.0213 & -0.3616 & 0.1183 & 11.2397 & -2.8137 & 00 & 26 \\
March & -0.0031 & -0.3893 & 0.3233 & 1.8952 & -0.0844 & 0.3797 & 26 \\
April & -0.0035 & -0.2333 & 0.2238 & 1.7653 & -0.2885 & 0.3799 & 26 \\
May & 0.0163 & -0.0931 & 0.2396 & 2.3908 & 1.0748 & 0.0214 & 26 \\
June & 0.0509 & -0.0904 & 0.2879 & 1.4775 & 1.0064 & 0.0845 & 26 \\
July & -0.0081 & -0.133 & 0.1869 & 0.3974 & 0.6904 & 0.3981 & 26 \\
August & 0.0109 & -0.1666 & 0.1696 & 1.7085 & 0.016 & 0.4732 & 26 \\
September & 0.0251 & -0.0588 & 0.3279 & 10.188 & 2.7519 & 00 & 26 \\
October & 0.0322 & -0.1621 & 0.5692 & 12.9692 & 2.9903 & 00 & 26 \\
November & 0.0191 & -0.1814 & 0.2545 & 0.4085 & 0.6453 & 0.4465 & 26 \\
December & -0.0046 & -0.2871 & 0.1239 & 11.4431 & -2.6359 & 00 & 25 \\
\hline
\end{tabular}

The regression model is run for three different sample periods: 1987-1996, 1987-2006 and 1987-2012. Table 3 exhibits regression results for the partial sample period January, 1987 to December, 1996. The first devastating stock market crash in Bangladesh was recorded in 1996. Though results are not significant, January effect is visible during 1987 to 1996; the difference between the mean return in January and December is negative and while it is positive for January. Only for three months, i.e., march, June and October, the return difference between January and the $i$ th month of the year is positive. 
Table 3. Regression analysis for period 1987-1996 (dependent variable: logarithmic return)

\begin{tabular}{|c|c|c|c|c|}
\hline & Coefficient & Std. Error & t-ratio & $p$-value \\
\hline Intercept (C) & 0.0306747 & 0.0334339 & 0.9175 & 0.36096 \\
\hline$D_{\mathrm{Feb}}$ & -0.0344926 & 0.0460854 & -0.7484 & 0.45583 \\
\hline$D_{M a r}$ & 0.0212339 & 0.0460854 & 0.4608 & 0.64591 \\
\hline$D_{A p r}$ & -0.00329977 & 0.0460854 & -0.0716 & 0.94305 \\
\hline$D_{\text {May }}$ & -0.0493551 & 0.0460854 & -1.0709 & 0.28660 \\
\hline$D_{\text {Jun }}$ & 0.0225191 & 0.0460854 & 0.4886 & 0.62610 \\
\hline$D_{\text {Jul }}$ & -0.0320936 & 0.0460854 & -0.6964 & 0.48769 \\
\hline$D_{\text {Agu }}$ & -0.0242601 & 0.0460854 & -0.5264 & 0.59969 \\
\hline$D_{\text {Sep }}$ & -0.0002321 & 0.0460854 & -0.0050 & 0.99599 \\
\hline$D_{\text {Oct }}$ & 0.0470867 & 0.0460854 & 1.0217 & 0.30921 \\
\hline$D_{\text {Nov }}$ & -0.0410162 & 0.0460854 & -0.8900 & 0.37546 \\
\hline$D_{\text {Dec }}$ & -0.0669186 & 0.0460854 & -1.4521 & 0.14941 \\
\hline R-squared & 0.103421 & & sted R-squared & 0.011250 \\
\hline
\end{tabular}

Note: *** indicates significant at $1 \%$ level; $* *$ indicates significant at $5 \%$ level; * indicates significant at $10 \%$ level.

Table 4 shows regression results for the partial sample period January, 1987 to December, 2006. In this sample period, the mean return for January is negative while the June effect has become prominent and visible.

Table 4. Regression analysis for period 1987-2006 (dependent variable: logarithmic return)

\begin{tabular}{|c|c|c|c|c|}
\hline & Coefficient & Std. Error & t-ratio & p-value \\
\hline Intercept (C) & -0.00911204 & 0.0222632 & -0.4093 & 0.68272 \\
\hline$D_{\mathrm{Feb}}$ & -0.00755711 & 0.0310889 & -0.2431 & 0.80816 \\
\hline$D_{M a r}$ & -0.007332 & 0.0310889 & -0.2358 & 0.81377 \\
\hline$D_{\text {Apr }}$ & 0.00236818 & 0.0310889 & 0.0762 & 0.93935 \\
\hline$D_{\text {May }}$ & 0.0242246 & 0.0310889 & 0.7792 & 0.43667 \\
\hline$D_{J u n}$ & 0.0638846 & 0.0310889 & 2.0549 & $0.04103(* *)$ \\
\hline$D_{J u l}$ & 0.000372806 & 0.0310889 & 0.0120 & 0.99044 \\
\hline$D_{A g u}$ & 0.0150277 & 0.0310889 & 0.4834 & 0.62929 \\
\hline$D_{\text {Sep }}$ & 0.034011 & 0.0310889 & 1.0940 & 0.27512 \\
\hline$D_{O c t}$ & 0.0478835 & 0.0310889 & 1.5402 & 0.12490 \\
\hline$D_{\mathrm{Nov}}$ & 0.0134554 & 0.0310889 & 0.4328 & 0.66557 \\
\hline$D_{D e c}$ & -0.00306415 & 0.0310889 & -0.0986 & 0.92157 \\
\hline R-squared & 0.051804 & & Adjusted R-squared & 0.005856 \\
\hline
\end{tabular}

Note: $* * *$ indicates significant at $1 \%$ level; $* *$ indicates significant at $5 \%$ level; * indicates significant at $10 \%$ level. 
Table 5 presents regression results for the whole sample period, i.e., 1987 to 2012 . The coefficients for all the dummy variables, except June \& October, are statistically insignificant.

Table 5. Regression analysis for period 1987-2012 (dependent variable: logarithmic return)

\begin{tabular}{|c|c|c|c|c|}
\hline & Coefficient & Std. Error & t-ratio & $p$-value \\
\hline Intercept (C) & -0.0195613 & 0.0193729 & -1.0097 & 0.31345 \\
\hline$D_{\mathrm{Feb}}$ & -0.00170076 & 0.0271327 & -0.0627 & 0.95006 \\
\hline$D_{\text {Mar }}$ & 0.016498 & 0.0271327 & 0.6080 & 0.54362 \\
\hline$D_{A p r}$ & 0.0161052 & 0.0271327 & 0.5936 & 0.55325 \\
\hline$D_{\text {May }}$ & 0.0358891 & 0.0271327 & 1.3227 & 0.18694 \\
\hline$D_{J u n}$ & 0.0705038 & 0.0271327 & 2.5985 & $0.00983(* * *)$ \\
\hline$D_{J u l}$ & 0.0114164 & 0.0271327 & 0.4208 & 0.67423 \\
\hline$D_{\text {Agu }}$ & 0.0304651 & 0.0271327 & 1.1228 & 0.26242 \\
\hline$D_{\text {Sep }}$ & 0.0446364 & 0.0271327 & 1.6451 & 0.10100 \\
\hline$D_{\text {Oct }}$ & 0.0517254 & 0.0271327 & 1.9064 & $0.05756\left(^{*}\right)$ \\
\hline$D_{\text {Nov }}$ & 0.0386147 & 0.0271327 & 1.4232 & 0.15573 \\
\hline$D_{D e c}$ & 0.0149939 & 0.0273974 & 0.5473 & 0.58460 \\
\hline R-squared & 0.045889 & & Adjusted R-squared & 0.010670 \\
\hline
\end{tabular}

Note: *** indicates significant at $1 \%$ level; ** indicates significant at $5 \%$ level; * indicates significant at $10 \%$ level.

Figure 2 exhibits average monthly return during 1987 through 2012. Average return for January, February, March, April, July and December is negative. Average return for the month June is 5.09 percent or 61.08 percent annually. Also, the R-squared is comparatively low. July, first month of the fiscal year in Bangladesh, also takes negative return which raises serious question about validity of tax-loss selling hypothesis.

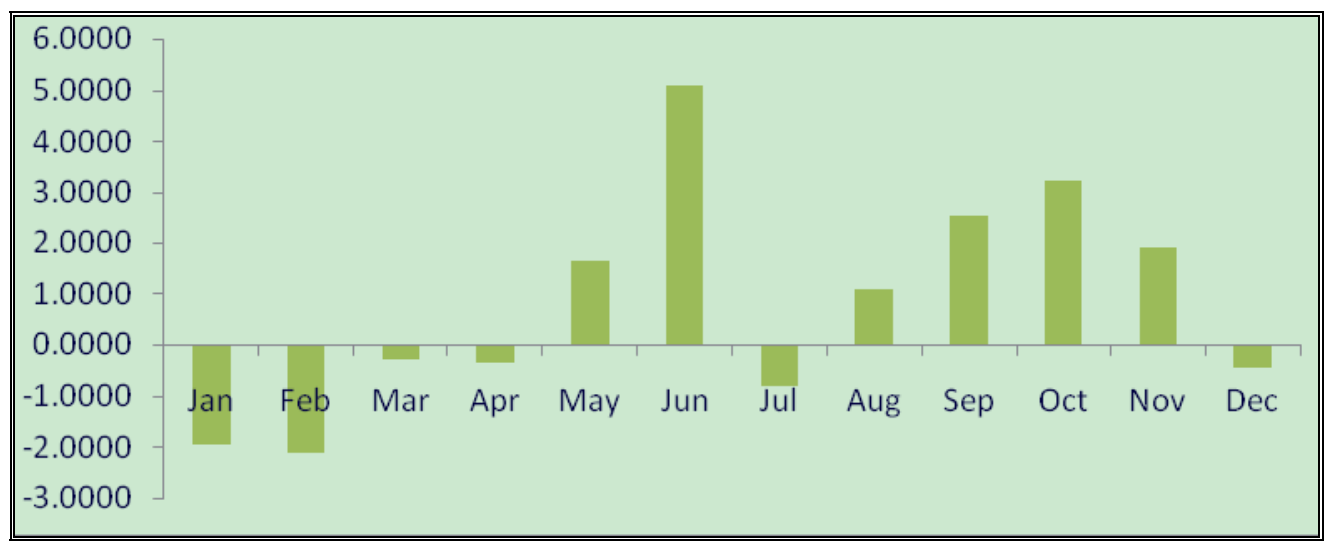

Figure 2. Mean monthly market return during 1987-2012

Apart from a positive June effect, the results, on overall, does not seem to support existence of January anomaly in Dhaka Stock Exchange (DSE) in Bangladesh. These results are not consistent with Chowdhury (2005). Moosa (2007) attributed the vanishing January effect to: (i) changes in accounting standards that do not make as great a distinction as in the past between realized and unrealized capital gains and losses; (ii) changes in the tax 
treatment of realized and unrealized gains/losses; and (iii) lower marginal tax rates, which dampens the incentive to engage in tax motivated trading.

Existence of significant June return is in direct violation of efficient market hypothesis since investors can take benefit from significant positive return in June.

\section{Conclusion}

During 1987 through 2012, January anomaly is not found in Dhaka Stock Exchange (DSE) in Bangladesh. The result is opposite of what Chowdhury (2005) discovered. In fact, during the sample period, mean stock return in December to April was negative. July is the first month of the financial year in Bangladesh, and Absence of significant positive return in July rejects usefulness of tax-loss selling hypothesis.

However, a significant positive June anomaly has been detected in DSE which raises serious question against efficient market hypothesis. Existence of June anomaly in DSE enables the investors to forecast the future stock prices by observing the current trend in stock market and can devise investment strategies which may help them to outperform the market.

\section{References}

Asteriou, D., \& Kovetsos, G. (2006). Testing for the existence of the January effect in transition economies. Applied Financial Economic Letters, 2(6), 375-381. http://dx.doi.org/10.1080/17446540600706817

Bahadur, K. C. F., \& Joshi, N. K. (2005). The Nepalese stock market: efficiency and calendar anomalies. Economic Review, 17(17).

Berges, A., Mcconnel, J. J., \& Schlarbaum, G. G. (1984). The turn of the year in Canada. Journal of Finance, 39(1), 185-192. http://dx.doi.org/10.1111/j.1540-6261.1984.tb03867.x

Branch, B. (1977). A tax loss trading rule. Journal of Business, 50(2), 198-207. http://dx.doi.org/10.1086/295930

Chowdhury, S. S. M. (2005). Seasonal anomalies in the DSE stock returns. Retrieved from http://www.saeed.xenexbd.com/pages/research.php

Dyl, E. (1977). Capital gains taxation and year-end stock market behavior. Journal of Finance, 32(1), 165-175. http://dx.doi.org/10.1111/j.1540-6261.1977.tb03250.x

Fama, E. F. (1970). Efficient capital markets: A review of theory and empirical work. Journal of Finance, 25(2), 383-417. http://dx.doi.org/10.2307/2325486

Floros, C. (2008). The monthly and trading month effects in Greek stock market returns: 1996-2002. Managerial Finance, 34(7), 453-464. http://dx.doi.org/10.1108/03074350810874415

Fountas, S., \& Segredakis, K. N. (2002). Emerging stock markets return seasonalities: the January effect and the tax-loss selling hypothesis. Applied Financial Economics, 12(4), 291-299. http://dx.doi.org/10.1080/09603100010000839

Gultekin, M. N., \& Gultekin, N. B. (1983). Stock market seasonality: International evidence. Journal of Financial Economics, 12(4), 469-481. http://dx.doi.org/10.1016/0304-405X(83)90044-2

Haugen, R. A., \& Jorion, P. (1996). The January effect: Still there after all these years. Financial Analysts Journal, 52(1), 27-31. http://dx.doi.org/10.2469/faj.v52.n1.1963

Haugen, R. A., \& Lakonishok, J. (1988). The incredible January effect: the stock market's unsolved mystery. Homewood, Illinois: Dow Jones-Irwin.

Hellstrom, T. (2002). Trends and calendar effects in stock returns (Working Paper). Retrieved from http://www.citeseerx.ist.psu.edu/viewdoc/summary?

Kato, K., \& Schallheim, J. S. (1985). Seasonal and size anomalies in the Japanese stock market. The Journal of Financial and Quantitative Analysis, 20(2), 243-260. http://dx.doi.org/10.2307/2330958

Keim, D. (1983). Size-related anomalies and stock return seasonality: Further empirical evidence. Journal of Financial Economics, 12(1), 12-32. http://dx.doi.org/10.1016/0304-405X(83)90025-9

Lindley, J., Liano, K., \& Slater, S. (2004). The strength of the tax effect at the turn of the year. Working Papers, No. 6-2004.

Maghayereh, A. (2003). Seasonality and January effect anomalies in an emerging capital market. The Arab Bank Review, 5(2), 25-32. 
Mehdian, S., \& Perry, M. J. (2002). Anomalies in U. S. equity markets: A re-examination of the January effect. Applied Financial Economics, 12(2), 141-145. http://dx.doi.org/10.1080/09603100110088067

Mills, T. C., \& Coutts, J. A. (1995). Calendar effects in the London Stock Exchange FT-SE Indices. European Journal of Finance, 1(1), 79-94. http://dx.doi.org/10.1080/13518479500000010

Mills, T. C., Siriopoulos, C., Markellos, R. N., \& Harizanis, D. (2000). Seasonality in the Athens Stock Exchange. Applied Economics Letters, 10(2), 137-142.

Moosa, I. A. (2007). The Vanishing January Effect. International Research Journal of Finance and Economics, 7, 92-103.

Nassir, A., \& Mohammad, S. (1987). The January effect of stocks traded on the Kuala Lumpur stock exchange: an empirical analysis. Hong Kong Journal of Business Management, 5, 33-50.

Ogden, J. P. (1990). Turn-of-Month evaluations of liquid profits and stock returns: A common explanation for the monthly and January effects. Journal of Finance, 45(4), 1259-1272. http://dx.doi.org/10.1111/j.1540-6261.1990.tb02435.x

Pandey, I. M. (2002). Is there seasonality in the SENSEX monthly returns? Working Paper, No. WP 2002-09-08. Retrieved from http://www.iimahd.ernet.in/publications

Rathinasamy, R. S. (2004). Robust test of the January effect in stock markets using Markov-Switching model. Journal of Financial Management and Analysis, 17(1), 22-33.

Reinganum, M. (1983). The anomalous stock market behavior of small firms in January. Journal of Financial Economics, 12(1), 89-104. http://dx.doi.org/10.1016/0304-405X(83)90029-6

Roll, R. (1983). Vas ist das? The turn-of-the-year effect and the return premia of small firms. Journal of Portfolio Management, 9(2), 18-28. http://dx.doi.org/10.3905/jpm.1983.18

Rossi, M. (2007). Calendar anomalies in stock returns: evidence from South America. Bachelor Thesis, Lappeenranta University of Technology.

Rozeff, M., \& Kinney, W. (1976). Capital market seasonality: The case of stock returns. Journal of Financial Economics, 3(4), 379-402. http://dx.doi.org/10.1016/0304-405X(76)90028-3

Schwert, G. W. (2002). Anomalies and market efficiency. Working Paper, No. FR 02-13. Retrieved from http://schwert.ssb.rochester.edu/hbfech15.pdf

Shin, K. (2003). Characteristics of the Asian and U.S. stock markets. Retrieved from http://www.kmfa.or.kr/paper/annual/2003/anni03_06.pdf

Strong, N. (1992). Modeling abnormal returns: a review article. Journal of Business, Finance and Accounting, 19(4), 533-553. http://dx.doi.org/10.1111/j.1468-5957.1992.tb00643.x

Wachtel, S. B. (1942). Certain observations on the seasonal movement in stock prices. Journal of Business, 15(2), 184-193. 